EURASIAN RESEARCH JOURNAL,

ERJ, Vol. 3, No. 2, pp. 19-32, July 2021

https://doi.org/10.53277/2519-2442-2021.2-02

ISSN 2519-2442, KAZAKHSTAN

Research Article

\title{
THEORIZATION IN IR AND THIRD WORLD STATES: THE PROMISE OF HISTORICAL SOCIOLOGY IN EXPLAINING THE NEXUS BETWEEN DOMESTIC AND INTERNATIONAL SPHERES
}

\author{
Yihenew Wubu ENDALEW
}

1 Ankara Yildrim Beyazit University, 06760 Ankara, Turkey; e-mail: yihenew.wubu@amu.edu.et;

\begin{abstract}
Until alternative theories that sought a serious consideration of third world states in International Relations (IR) proliferated in the last quarter of the $20^{\text {th }}$ century, knowledge production remained monopolized by dominant Western-centered theories. Historical Sociology in International Relations (HSIR) is one of the approaches that aimed at directing IR towards more inclusive inquiries that acknowledge temporal and spatial variance; especially against ahistorical and 'asociological' foundations of Neorealism. Despite this motivation, most of the studies and debates within HSIR are concentrated on illustrating the approach's applicability in the study of Western states. Through a review of the available literature, this paper aims to demonstrate the promise of HSIR in explaining the relationship between domestic and foreign affairs of third world states. To achieve this objective, the paper mainly draws from the works of John Hobson and Fred Halliday and suggests the incorporation of third world states in the inquiries and debate within HSIR.
\end{abstract}

Key Words: International Relations, Theory, Historical Sociology, Third World States, Domestic Domain, International Domain 


\section{INTRODUCTION}

Since IR emerged as a separate discipline in the aftermath of the First World War (WWI), it has gone through intractable debates on theoretical and related issues. Concerning debates in IR, Fred Chernoff (2007: 1-2) identified foreign policy matters, theoretical and metatheoretical debates as the three areas of contentions. Foreign policy-related debates focus on identifying the right actions about specific issues of foreign relations. Theoretical debates take place in the rivalry among different perspectives to explain main questions in IR, and metatheoretical debates are philosophical inquiries that intend to come up with the best theory. According to Robert Jackson and Georg Sorensen (2013: 33-34), theoretical debates in IR received huge attention in the evolution of the discipline. Four major debates took place in IR so far: between Realism and Liberalism in the interwar period, Traditionalism and Behavioralism, the neo-debate (between Neorealism, Neoliberalism, and Neo-Marxism), and Rationalism and Reflectivism. Jackson and Sorensen added that, among other things, these debates mainly sought to answer how states emerged, what determines the nature of their interactions, and the causes of peace and war.

As John Hobson and Stephen Hobden rightly pointed out, in the lingering IR theoretical debates, the tenacious attitude of 'gate keepers' of mainstream theories that aim at defending theoretical 'purity, consider approaches devised to engage to entertain diverse voices as unauthentic and not worthy of shaping IR inquiries (Hobson and Hobden, 2002: 267). Thus, beyond the competition between dominant theories, there is a tendency to sideline endeavors that aim either pushing dominant theories to widen their scope and the approaches that intend to mitigate the gap in theorization through new perspectives. Since no agreement is reached on answers to the above basic questions, theorization in IR is trapped in Western-dominated theoretical debates. The challenge resulted from this is not limited to being wasted in the unending battle between dominant theories that focus on fiercely defending theoretical tenets, but lack of inclusiveness because of their Western-centeredness is also another problem. Concerning this, the limited attention given to third world states ${ }^{2}$ is one of the major criticisms directed against IR.

However, theoretical entanglements of IR should not be overstated. The utilization of theories and competing interaction between them is not peculiar to IR and it is common in other disciplines too. Regarding this fact, Fred Halliday pointed out that theorization is also a core academic practice in mathematics, philosophy, sociology, and other disciplines. What makes theorization in IR different is that "more than other branches of social science", it needs to focus on "explanation" rather than "prediction". But too much focus on the latter has resulted in unending theoretical controversies. Against this trend, Halliday recommends that theorization in IR needs to be engaged in explaining "historical events and processes" so that the relation between states and the international

\footnotetext{
2 The author is cognizant of criticism against the term third world states and employed it in the paper deliberately because of its relevance to represent states that are under consideration. As B. R. Tomlinson (2003: 307-209) indicated, states denoted by the term 'third world' or 'third world states' have evolved through time. The term 'third world states' emerged during Cold War to refer to states that were out of the US and the Soviet blocks. However, gradually its meaning became coined with states that have dire political and economic conditions, mainly post-colonial states. Though there are significant disparities between these states and despite the difficulty to come up with a list of third world states, the term roughly used to refer to states of South America, Asia, and Africa. Thus, the term 'third world states' is used in this paper generically to refer to underdeveloped post-colonial states separately from its negative connotations.
} 
system can be understood; rather than attempting to produce abstract prediction principles (Halliday, 2005: 21). The attempt to come up with generalized principles that can predict the behavior of states has dominated the discipline which in turn is responsible for IR theories' treatment of third world states as aberrations. The insignificance of the attention given to non-Western regions and the states within them has led to the designation of IR as a Western-dominated discipline (Acharya and Buzan, 2010: 6-7).

Thus, theorization in IR has been accused of being 'Eurocentric' as it fundamentally focuses on promoting and protecting European values rather than trying to explain international affairs without prejudice (Hobson, 2012: 1). The dominance of the West in IR is expressed in two ways. Firstly, most of the dominant theories are founded on "Western philosophy, political theory and/or history". Secondly, mainstream theories depict European history as the history of the world (Acharya and Buzan, 2010: 6). Thus, third-world states are bystanders to IR theories as they are not seriously considered as relevant entities to the task; and inquiries that focus on these states are not welcome into this theorization scene. The paradox we infer from this problem of theorization is that though IR purports to be an international discipline, it marginalizes third world states which represent a significant portion of the world states and population thereby contradicting the framing of its scope.

The Western dominance in IR theory is well documented. About the lack of inclusiveness in IR theory, Halliday observed that inquiries that stood against tenets of dominant theories sought to reconceptualize society, state, and their interaction with the interaction system. When the attempt to change this emerged in the 1970s, it brought a theorization "impasse" in which neither dominant theories were willing to correct their shortcomings nor alternative theories were able to emerge successfully against dominant approaches (Halliday, 1994: 74). As part of this dynamic, the dialogue between IR and Sociology in the 1980s emerged resulting in the devising of HSIR. Hence, HSIR was one of the results of the call for a multi-disciplinary and flexible approach in IR especially for the sake of remedying static and ahistorical Neorealist conceptions (Lawson, 2006: 398).

This article intends to illustrate the promise of HSIR in demonstrating the inseparability of domestic and international realms. In other words, it tries to illustrate the appropriateness of the approach to explain third world states and their behavior in the international system. To achieve this objective, the paper relies on historical analysis through the utilization of secondary data. Accordingly, the paper is divided into three parts. The first section discusses the place of third world states in established IR theories and uncovers the gap in terms of dealing with third world states. The second section focuses on the emergence HSIR as an alternative approach in IR and its link with the study of the third world states. The last section of the paper addresses the advantages of HSIR in illustrating the domestic conditions of third world states and the foreign realm. The article ends by making suggestions on how the debate and inquiries within HSIR can incorporate third world states and avoid replicating the problem of lack of inclusiveness that mainly exists in mainstream IR theories. 


\section{THEORIZATION IN IR AND THIRD WORLD STATES}

As it is indicated in the introduction section, the dominance of the West in theorization and lack of serious consideration for other parts of the world has motivated some IR scholars to pursue either integration of these regions within the focus of dominant theories or to devise alternative approaches that solve the problem. This section briefly assesses how third world states are treated in some established theories and other revising approaches. Mainstream IR theories consider third world states as entities that have nothing to contribute to knowledge production. Since the way third world states are dealt with in all theories cannot be discussed in this short paper, only some of them are briefly presented here. To begin with Realism, Hans Morgenthau argued that third world states are irrelevant in academic endeavors that aim to understand world politics. For instance, Morgenthau mentioned that Africa lacks history before WWI. For him, Africa is void of any significant politics worth serious consideration for the sake of understanding the world (Chipaikie and Knowledge, 2018: 2). It is easy to estimate the effect of this comment given by a founder of the most influential IR theory on the trend of how third world states were treated since then in IR theories.

The fact third world states are depicted as insignificant in mainstream IR theories is also evident in Neorealism. For instance, one of the key figures in Neorealism, Kenneth Waltz, in Theory of International Politics (Waltz, 1979: 72-73) argued that "a general theory of international politics is necessarily based on the great powers". He claimed that the politics of weak states can be explained by a general theory founded on the features of powerful states. Waltz analogously presented his argument by stating the similarity of advancing a theory of IR founded on the realities of weak states is with trying to develop a general economic theory based on small businesses that are less decisive in determining the conditions of the whole market. Waltz claimed that it would be meaningless "to construct a theory of international politics based on Malaysia and Costa Rica".

Neo-liberalism has also the same problem towards underdeveloped regions in general. For instance, Liberalism's conviction is evident in Francis Fukuyama's argument who claimed that Liberalism's emergence as the sole ideology of humanity in the post-Cold War era guarantees prosperity for all the world as the only viable political and economic standard. He added that this is not a coincidence but the result of a long battle between different ideologies. In his view, fascism and communism were the only rivals to liberalism which faded away when Liberalism emerges triumphant at the end of the $20^{\text {th }}$ century. Though he believed it is necessary to deal with approaches that can resolve the challenges which liberalism is unable to address, he asserted that there is no need to waste time on perspectives that come from marginal regions. In Fukuyama's words, "it matters very little what strange thoughts occur to people in Albania or Burkina Faso, for we are interested in what one could in some sense call the common ideological heritage of mankind" (Fukuyama, 1989: 9).

However, despite the above explicitly stated negative connotations and rejection by dominant theories towards third world states, IR experts in the third world are engaged with the attempt of fitting states in these regions with notions of dominant theories. For instance, Cirino Ofuko (2009: 73-75) observed that in the immediate years of independence, the study of African states was dominated by structural-functionalist theory that relied on the leadership merit of native 
individual leaders of post-colonial states in the attempt to explain the fate of post-colonial states in the international system. But it did not take long to the euphoria of independence which motivated scholars to analogize third world states with western states to wither away following serious political and economic challenges faced.

Despite full membership of the third world states in the United Nations (UN) in the post-Second World War (WWII) era, the huge gap in terms of wealth and power was still evident. As a result, domestic problems became defining features of third world states which in turn affected their relationship with developed states and with international organizations. The shift in norms of sovereignty ensured the survival of states that could not reciprocate and the development-based cooperation framework that expected developed states not only to avoid interference but also to facilitate the flow of knowledge and resources meant to mitigate poverty in third world states. From the side of third world states also, there emerged a tendency to claim this as a right on the ground of compensation for past injustice. The emergence of multi-governmental and governmental organizations that work on development issues in the third world, mainly the specialized agencies of the UN made development the second most global agenda next to security (Jackson, 1990: 40-47). However, despite this development-centered international environment, conditions in third world states were deteriorating. As a result, economic and political challenges faced as the newly independent states influenced the study of third world states. Approaches that combinedly analyze domestic economic and political conditions as part of broad historical and contemporary global processes were employed to give insights on the formation of third world states and their domestic features.

In the 1970s, political instability and economic challenges were also partly exacerbated by the rise in the price of oil during 1970s which additionally eroded the optimism about the third world states; especially in states with non-oil economies (Clapham, 1996: 168). Overall problems third world states faced led to the emergence of various approaches influenced by Marxism that argue lack of development and other challenges as a product of historical exploitative relations imposed by Europe. As a result, perspectives including world-system theory, dependency theory, and post-colonial approaches emerged focusing on uncovering historical inequalities to explain conditions in the third world states and their foreign affairs. To begin with the world-system approach, Immanuel Wallerstein (1991: 13-26) advanced the study of global political economy centered on the evolution of capitalism across time and space resulting in the stratification of the world into the core, semi-periphery, and periphery. Accordingly, Wallerstein argued that the global political economy operates in a way that gears the periphery and semi-periphery towards realizing the prosperity of the core.

Originated in Latin America, dependency theory applied the state level Marxist analysis to the relation between powerful and weak states. Accordingly, it focused on the asymmetrical flow of surplus that took place for several centuries embedded in the relation between Europe and other parts of the world. For instance, Andre Gunder Frank (1978: 70-91), argued that the process of unequal economic exchanges brought an accumulation of capital in Europe leading to the process of industrialization and facilitated the emergence of global capitalism. Going beyond Latin America, dependency theory became an important tool 
in the study of other regions too. For instance, Walter Rodney's How Europe Underdeveloped Africa (1972: 106-346) claimed Africa's underdevelopment was the cost paid to develop Europe because of exploitations through slave trade and colonization. Among post-colonial approaches, Edward Said's orientalism also deserves our attention here. Said (2003: 3-28) argued that the nature of the interaction between Europe and other parts of the world was defined by the effect of Eurocentric identity and knowledge production. Said focused on how Europe which he termed as "the occident" racially defined the non-European or "the orient" determined the interventions of the former into the latter including colonial domination and exploitation.

The above Marxist-influenced and post-colonial approaches framed around the analysis of global political economy were important in shedding a light on the role of historical asymmetrical relations for contemporary realities in the third world states and internationally. However, beyond externalizing causal factors for contemporary realities in the third world states, they were unable to dethrone mainstream theories and fill the gap that existed in theorization in IR. Accordingly, mainly since the 1980 s alternative theories to devise a viable approach that could be applied in the study of states and their interaction within the international system. HSIR is part of this dynamic emerging as an approach to engaging with historically and sociologically embedded multi-disciplinary analysis to explain states and the international system. As it is discussed in detail in the next section, HSIR allows us to fill the gap that exists in dominant theories in explaining features of third world states by placing their emergence and evolution of their internal characters within a broader state-society-international system framework.

\section{HISTORICAL SOCIOLOGY AND THIRD WORLD STATES}

The interaction between IR and Sociology or 'sociological turn of IR' took place in the 1980s. This was a relatively recent development compared to the dialogue of IR with other disciplines like economics, political science, and political theory. The late attention given to historical sociology in the study of states and the international system is ill-fated given the approaches' suitability to study continuous and complex changes which simultaneously are core issues in IR. As a multi-disciplinary approach, among many of its advantages, the broadness of the scope of issues that HSIR can be used to address is an asset in the study of states and the international system. In other words, this refers HSIR's suitability to give attention to issues that range from details of historical events that are ignored in mainstream theories to large-scale global developments (Lawson 2006: 397-398). HSIR also directs our attention towards wholistic narratives like the questions of how the social, economic, and political orders of the contemporary modern world evolved through time; thereby acknowledging the historical-rootedness and causal-dependence of the contemporary international system (Lawson, 2006: 403). This temporal and spatial variance that can be addressed in HSIR makes it a highly relevant approach to deal with commonalities and salient features of third world states and their foreign relations.

Hobson (2002: 13) defined HSIR as "a critical approach which refuses to treat the present as an autonomous entity outside of history but insists on embedding 
it within a specific socio-temporal place, thereby offering sociological remedies to the ahistorical illusions...". Lawson (2007: 4) also defined it as an approach that intends to uncover "the complexity that lies behind the interaction between social action (both deliberate and unintentional) and structural forces (socially constructed but with an enduring authority and dynamic of their own)". The common element of all definitions is that they underline the need to make historically and socially founded analyses. This shows the deviance of HSIR in comparison with ahistorical and asociological tenets of Neorealism thereby giving us the chance to recognize variance and change.

In introducing a vital work that included chapters contributed by experts known in other approaches, like Martin Shaw, Andrew Linklater, Barry Buzan, and Richard Little, Hobson indicated how the integration of other approaches with historical sociology can be fruitful in investigating major questions in IR. He summarized possible results of this dialogue into seven approaches that included neo-Weberian historical sociology, constructivist historical sociology, world systems historical sociology, critical historical materialist historical sociology, critical historical sociology, postmodern historical sociology, and non-Waltzian structural realist historical sociology as demonstrated in the works of Barry Buzan and Richard little and other (Hobson, 2002: 20-41). The bottom line of all the approaches is that despite they are different variants within HSIR, all agree on the need to recognize the role of history in shaping the present research agendas of IR, they acknowledge the importance of various sources of power, they agree on the need to grant society, state and the international system non-autonomous agency and they believe in the interconnectedness of domestic and international domains.

HSIR is a multi-disciplinary approach that enables us to include issues that matter beyond the confinements of one discipline. Especially the importance it accords to history makes HSIR suitable to grasp change and continuity in the role of social forces within states or state-society relations. It also upholds the constitutive relativity of the present features of states while it acknowledges historical roots. Thus, it helps to reveal the process of evolution of states that sheds a light on the endeavor to understand their present domestic and foreign agendas. However, it should be clarified that the use of history in theorization is not something confined to HSIR. The difference is that HSIR gives attention to history not only as a source of data to understand the past, but it is used to shape studies about the present too. Accordingly, HSIR upholds history not as an instrument to check the validity of theories, but it gives intrinsic attention for the sake of reconstructing IR studies that aim to explain questions of the present (Hobson, 2002: 5). As one of the competing approaches that emerged against the monopoly of Neorealism in IR, HSIR's assumptions are framed contradictorily against the former's tenets. To illustrate relevance to the study of third world states, especially about understanding the link between domestic and foreign realms, it is good to have a brief look at the principles of HSIR.

Some experts opted only implicitly asserting what constitutes their approach rather than attempting to list out principles of HSIR. According to Benno Tesche, this includes Halliday, who is well known to produce extensive works utilizing the approach mainly in the study of the Middle East in IR. Halliday abstained from coming up with an explicit list of principles and he was not 
assertive enough when confronted to point out the basis of his analysis (Tesche, 2011: 1088). However, Hobson (1998: 286-295) provided six principles of Historical Sociology as a move to respond to "six principles" of Realism by Hans Morgenthau. Hobson put history and change, multi-causality, multi-specialty, partial autonomy, complex change, and non-realist conception of state autonomy as guiding principles of HSIR. The importance of history and change is underlined to understand the root of the current international system and to investigate political, economic, and social changes within states. Unlike Neorealist fixation with military power, change in HSIR is understood as the result of a variety of sources of power including military, ideological, social, and economic. All sources of power are supposed to occur and operate in overlapping and intersecting manner at all levels one affecting the other non-autonomously. Thus, one who wants to grasp the whole picture of change needs to take into consideration the role of all sources of power. The change that occurs in this way is not linear, rather it is characterized by continuity and discontinuity. At last, unlike the Neorealist view which gives exclusive agency to the international system on the states on one hand, and the state over society on the other, HSIR considers all entities non-autonomous.

Thus, HSIR's benefit in the study of third world states emanates from the above principles as flexible and multi-disciplinary approach. Going beyond the search for yardsticks to predict state behavior, analysis founded on principles of HSIR can address not only specific foreign policy issues but also enables inclusively engage in other major questions in IR. For instance, an inquiry of HSIR can engage in historically and socially founded investigations to answer questions including whether states emerge first and brought the international system into existence, or vice versa. How the foreign realm affects states' behavior and what is the agency of the state over international relations? What role does society play in determining the features of the state and the international system? Specific to third world states, HSIR helps to investigate the role the international realm played in their formation, and how the international and domestic dynamics interact both historically and contemporarily. In the next section, the understanding of the nexus between domestic and international affairs in HSIR and its implication for third world states is discussed.

\section{COALESCENCE OF THE DOMESTIC AND THE INTERNATIONAL REALMS}

As it is mentioned in the previous section, the question of which one emerged first, either states or the international system, is one of the debates that exist in IR. Hobson (2002: 22) pointed out that Neorealism considers the international system as an entity that immediately came into existence following the interaction between states. Moreover, it views domestic and international domains as clearly separated entities and denies the agency of states in shaping the nature of the international system. However, HSIR considers the domestic and international realms as continuously interacting realms that change continuously retaining some of their features. This notion has huge implication in our understanding of the formation of states and their behavior in the international system generally and in third world states specifically. 
HSIR sees state formation not only in third world states but also in European states mainly as the result of interaction between domestic and global phenomena. This notion has enabled to situate state formation in broader global political and economic contexts rather than as the sole process of internal emergence of coercive domination. In this regard, Halliday (1999: 187-188) stated that that there is huge evidence to denounce the Neorealist view which regards the international system spontaneously emerged as the result of interaction between states. To illustrate this, he pointed out the role of the global activities that enriched the British Empire thereby determining its emergence as a wealthy and powerful state. Halliday added that the Thirty Years War and the Westphalian Treaty were continental developments that resulted in the formation of European states. State formation in third world states, as it is evident in Asia, Latin America, and Africa, is the result of a global enabling environment, mainly the process of colonialization and decolonization.

Assessment of literature about state formation in Latin America by Mark Berger (2000: 153-158) revealed that the legacy of colonialism remains central to the study of state formation in the region contemporarily. Colonial establishments of European powers that started in the $15^{\text {th }}$ century ended with the creation of the present Latin American states in the post-WWII era. Accordingly, despite the role of differing internal social and economic realities, inherited colonial institutions were important in defining the nature of these states including their emergence and the prolonged civil war that ravaged most of the states in the post-independence era. The same is true in Africa where violent and fiercely competitive scrambling took place even in comparison with other colonized regions. Especially, the principle of effective control, one of the principles adopted in the Berlin Conference of 1884-85, was an important factor for the intensification of the rivalry and the violent nature of the occupation. It only took few decades for the whole of Africa to fall into the hands of European powers.

Thus, state formation in third world regions was the result of external domination which shows the role of the international realm in their formation. As it is indicated above, the international system did not only created states but also preserves them through international organizations and their norms. Not only in their formative process, the intertwined domestic and international system is also another feature, because the line that divided domestic conditions into third world states and the role of the foreign realm is blurred. Significantly, major domestic political and economic events in third world states are either enabled or imposed by external opportunities and constraints, respectively. From direct and proxy interference in the political sphere to the unfair economic competition within the globalized economy, third world states are vulnerable to external influence. At the same time, the foreign sphere is also a source of military and security support, a partner in development endeavors that helps to mitigate domestic economic and social agendas and the like. As Halliday correctly pointed out, the international sphere is not only a threat against the survival of third world states. Since they continuously maneuver to secure resources that can help them to appear stronger than what they can achieve with domestic resources, the international system is perceived both as a resource and as a constraint (Halliday, 1994: 84-85).

The nexus between domestic and foreign realms is approached from different 
perspectives in HSIR. For instance, while Theda Skocpol and Halliday focus on the analysis of revolutions, Hobson focuses on international trade and political economy to illustrate the indispensability of the two domains. According to Halliday, revolutions are like volcanoes or earthquakes. Taken this analogy into account, HSIR treats revolutions as events that "occur in particular places, as do volcanoes or earthquakes, but we can only understand these specific explosions by looking at broader contexts and structures... not just at the site of the explosion itself". Similarly, he suggests that the attempt to understand the implications of revolutions should not be limited to the national and social contexts in which they take place; rather they should be treated as "a broader transnational formation, they become part of the ongoing interaction of specific states with the international system". In line with this, Halliday observed about the revolution in the Peoples' Democratic Republic of Yemen (PDRY) that it was a primary determinant of the foreign relation pursued. He added that like what happened in France in the 1790s, in China in the 1960s, the foreign policy of Yemen was the result of internal political dynamics. Halliday observed also "the degree to which revolutionary regimes can themselves be drawn into rivalries and conflict, evident in Sino-Soviet and Sino-Vietnamese relations, is also evident in the PDRY's uneasy dealings with Ethiopia, Libya, and Iraq" (Halliday, 1990: 229).

It is important to address the ongoing debate within HSIR here with a particular focus on the role of the state in the international system. Hobson (2002: 70-73) classified works that utilized HSIR in to first and the second wave of neo-Weberian historical sociologists. Hobson put Skocpol's analysis of social revolutions in this category and criticizes her for failing to grant the state an agency despite her claim to "to bring the state back in" to theorization in IR. In Hobson's view, despite critiquing Neorealism for denying the state its agency in the international system, there is no difference between Skocpol's depiction of the role of the international system in social revolutions and Waltz's structural Neorealism as both give agential power to international structure in shaping state behavior. In this regard, Skocpol's emphasis on a war between states as the cause of revolutions, when citizens are not lenient to shoulder the increasing cost of war, asserts none other than Waltz's argument of the anarchic structure as a determinant of state behavior.

Hobson (2002: 74-77) classified himself, Stephen Hobden and Michael Mann as part of the second wave of neo-Weberian historical sociologists and argued that their analysis acknowledges stratification of agency and multiple sources of power. He added that such analysis brought the state 'back in' into theorization in IR. Based on the above notions, Hobson depicts the international system not as a sole anarchic arena but as a pool of both opportunities and challenges. From the perspective of state-society relations, he classified states into two types: strong and weak. Accordingly, the former represents a state that is deeply embedded across all sections of the society while the latter relies on patrimonial relations with some sections of society and has exploitative relations with the majority of the society. Domestic state capacity also differs as a state may enjoy high agency over domestic issues like the $19^{\text {th }}$ century Britain that resorted to promoting free trade while Germany and Russia which had low agency were pursuing protectionism. Going beyond the Neorealist security-centered threat of the international system, Hobson focuses on the fiscal crisis as the main challenge against states, which can be the result of either security problems (increase 
in the cost of war) or global economic recession. Under these scenarios, states employ either tariff protectionism or promote free trade based on whether they can secure finance by imposing the cost on domestic sources (income taxation). In other words, states with high domestic agency resort to free trade while those with low domestic agency rely on tariff protectionism (Hobson, 2003: 205-210).

Generally, the utilization of HSIR following Hobson's line of Neo-Weberian analysis is important in the study of third word states because of several reasons. Firstly, his configuration of agency structure at three levels i.e., at the society, state, and international levels, and the conception of the international system as a domain of both opportunities and challenges enable us to study third world states from bottom-to-top direction and vice versa. Secondly, his focus on continuity and change both at the state and international level with explicit recognition of the relevance of history in shaping research problems of the present helps to analyze the historical context in which global developments facilitated the emergence of states which also continued to play important role in their domestic and foreign affairs contemporarily. Accordingly, the challenges and opportunities the international system offers to third world states can help us reveal the nexus between domestic and foreign affairs of third world states. However, the problem in debates within HSIR and the inquiries conducted by its leading experts is a similar lack of interest towards underdeveloped regions like Asia and Africa.

\section{CONCLUSION}

Theoretical debates among mainstream theories give no significant attention to the study of third world states and their foreign affairs. Since the 1980s, as the result of the motivation to mitigate this and other gaps, the debate expanded into another dimension following the proliferation of theories that sought the dominance of mainstream IR theories, especially the monopoly of Neorealism. It is this fact that triggered some scholars to refer to IR as a Western discipline. HSIR is one of the approaches devised to free IR from the search of rule-like principles based on the Western experience and to do a reflective analysis that gives equal attention to all states. While this was meant to correct the theorization challenge in the discipline, practically it only widened the existing problem. As these approaches attempted to penetrate IR's theorization scene, they were rejected by mainstream theories thereby pushing them to focus on the task of demonstrating vitality in the approaches study of Europe and the West.

As it is illustrated in Hobson's arguments discussed in the last section, though there are other disagreements, states' agency concerning society and the international system is the main point of difference both in the debate between mainstream theories and among experts that employ HSIR. Unlike the Neorealist view which grants the state absolute agency over society while depicting it as a passive entity that only attempts to fit the requirement of the international system, HSIR grants non-autonomous agency for each of the actors. HSIR gives a practical solution to the debate on the importance that should be accorded to the state in IR by giving a non-autonomous agency that creates a balance between the role of non-state, state, and international actors. This is huge deviance from the state-focused and anarchic depiction of realism, different from a reductionist 
view of the state by Marxist approach, and the overemphasis given to international organizations and norms by liberalism.

However, though HSIR is important to advance inclusive research agendas in IR, the West still receives much of the attention. Hence, it is possible to say that even the debate between first and second neo-Weberian historical sociology revolves around bringing the Western state 'back in' into IR theories against Neorealist denial of a state agency. Theda Skocpol's inclusion of China and Halliday's study of the Iranian, Ethiopian, and Yemeni revolutions are different from the above trend. While these studies have given attention to non-Western regions in IR, studies of revolutions are determined to be scarce as they did not take place in all states. Moreover, while the push to grant agency to the state may give more insights to study state-society relations rather than state-international system relations in the third world states as the result of their limited capacity to influence global developments. This is true regardless of their maneuver in search of opportunities within the international system. The influence of this is evident in more focus of the existing studies on Asia, Latin America and compared to studies Africa.

The above trend proves that, like what exists within dominant IR theories, HSIR follows the footstep of powerful and wealthy states and regions as the focus of inquiries that utilize this approach. If HSIR should seriously incorporate third world states, another debate within it is inevitable. This may include reconfiguration of concepts in HSIR should take into consideration realities in third world states. For instance, the Weberian conception of the state as coercive and administrative institutions that are independent of other bodies needs to be reconceptualized since third world states lack independent institutions that are autonomous from the policies and ideologies of governments. Moreover, the difference in terms of challenges and opportunities the international system offers also must be noted since threats third world states face and opportunities, they pursue are different from that of developed states.

The utilization of HSIR in the study of third world states will contribute meaningfully in the attempt to reconcile third world states with theorization in IR. The role of global events in the formation of third world states vis-à-vis the role of internal dynamics can be delicately addressed through HSIR. Challenges and opportunities of the international system of third world states can be approached from the perspective of broad global developments including colonization, emergence and expansion of capitalism, and globalization. In addition to understanding the global environment from which third world states emerged, the importance HSIR accords to state-society relations can be employed to study the effect of these events on the lives of the people at the grassroots level. War is not a prime threat of survival that third world states confront in post-WWII era as international organizations and norms granted survival of third world states, even though they lack the means to reciprocate against the actions of powerful states. How weak states exploit this international system in different forms including development and humanitarian aid, and security assistance to appear stronger than domestic resources allow can be used to frame foreign relation studies of these states. HSIR is also a useful tool to go beyond the security-focused analysis of survival by concentrating on challenges contemporary third world states face concerning issues like poverty reduction, environmental issues, and the problem of migration. 


\section{REFERENCES}

Acharya, Amitav and Barry Buzan (2010). "Why is there no non-western

international relations theory? An introduction an introduction?", In Amitav

Acharya and Buzan Barry (Eds.). Non-Western International Relations Theory: Perspectives on and Beyond Asia. New York: Routledge.

Berger, Mark (2000). "Specters of colonialism: Building post-colonial states and making modern nations in the Americas". Latin American Review 35(1): $151-171$.

Chernoff, Fred (2007). Theory and Metatheory in International Relations: Concepts and Contending Accounts. New York: Palgrave Macmillan.

Chipaike, Ronald and Matarutse H. Knowledge (2018). "The Question of African Agency in International Relations". Cogent Social Sciences, 4(1): 135152.

Clapham, Christopher (1996). Africa and the International System: The Politics of State Survival. Cambridge: Cambridge University Press.

Frank, Andre G. (1978). Dependent Accumulation and Underdevelopment. New York: New York University Press.

Fukuyama, Francis (1989). “The end of history?” The National Interest No. 16, pp. 3-18.

Halliday, Fred (1990). Revolution and Foreign Policy: The Case of South Yemen 1967-1987. Cambridge: Cambridge University Press.

Hobson, John (1998). "The historical sociology of the state and the state of historical sociology in international relations." Review of International Political Economy 5(2): 284-320

Halliday, Fred (1994). Rethinking International Relations. London: Macmillan.

Halliday, Fred (1999). Revolution and World politics: The Rise and Fall of the Sixth Great Power. Lomdon: Macmillan.

Halliday, Fred (2005). The Middle East in International Relations: Power, Politics and Ideology. Cambridge: Cambridge University Press.

Hobson, John (2002). "What is at stake in bringing historical sociology into international relations'? Transcending 'Chronofetishism' and 'Tempocentrism' in international relations". In John Hobson and Stephen Hobden (Eds.). Historical Sociology of International Relations. Cambridge: Cambridge University Press.

Hobson, John M. (2012). The Eurocentric Conception of World Politics: Western International Theory, 1760-2010. Cambridge: Cambridge University Press.

Hobson, John and Stephen Hobden (2002). "On the road towards a historicized world sociology". In John Hobson and Stephen Hobden (Eds.). Historical Sociology of International Relations (265-285). Cambridge: Cambridge University Press.

Jackson, Richard (1990). Quasi-States: Sovereignty, International Relations, and the Third World. Cambridge: Cambridge University Press. 
Jackson, Robert and Georg Sorensen (2013). Introduction to International Relations Theories and Approaches. Oxford: Oxford University Press.

Lawson, George (2007). "Historical sociology in international relations: Open society, research program and vocation". International politics 44(4): 343-368.

Lawson, George (2006). "The promise of historical sociology in international relations”. International Studies Review 8(3): 397-423.

Ofuho, Cirino (2009). “Africa: Teaching IR where it's not supposed to be”, in international relations scholarship around the world". In Tickner, Arlene and Ole Waever (Eds.). International Relations Scholarship around the World (71-85). London: Routledge.

Rodney, Walter. 2018. How Europe Underdeveloped Africa. London: Verso Books.

Said, Edward W. (2003). Orientalism. London: Penguin.

Teschke, Benno (2011). “Advances and impasses in Fred Halliday's international historical sociology: A critical appraisal”. International Affairs 87(5): 10871106.

Tomlinson, Tom B. R. (2003). "What was the Third World?" Journal of Contemporary History 38(2): 307-21.

Wallerstein, Immanuel (1991). The Politics of World-Economy: The States, Movements, and the Civilizations. Cambridge: Cambridge University Press.

Waltz, Kenneth (1979). Theory of International Politics. Berkley: AddisonWeley. 